\title{
Prevalence of Antibiotic Resistant Bacteria in Nigerian Fermented Food Condiments
}

\author{
Okafor Chibuanuli M \\ Molecular Research Foundation for Students and Scientists, Chisco Building, Nnamdi \\ Azikiwe University, Awka, Nigeria \\ Ikegbunam Moses N (Corresponding Author) \\ Molecular Research Foundation for Students and Scientists, Chisco Building, Nnamdi \\ Azikiwe University, Awka, Nigeria
}

Department of Pharmaceutical Microbiology and Biotechnology, Nnamdi Azikiwe University, Awka, Nigeria. E-mail: mn.ikegbunam@unizik.edu.ng

Nwachukwu Judith C

Molecular Research Foundation for Students and Scientists, Chisco Building, Nnamdi Azikiwe University, Awka, Nigeria

Department of Pharmaceutical Microbiology and Biotechnology, Nnamdi Azikiwe University, Awka, Nigeria

Ebenebe Ijeoma $\mathrm{N}$

Department of Pharmaceutical Microbiology and Biotechnology, Nnamdi Azikiwe University, Awka, Nigeria

Nnanna Joy C

Department of Pharmaceutical Microbiology and Biotechnology, Nnamdi Azikiwe University, Awka, Nigeria

Received: December 23, 2019 Accepted: January 19, 2020

doi:10.5296/jbls.v11i1.16383 URL: https://doi.org/10.5296/jbls.v11i1.16383 


\section{Abstract}

Food borne diseases remain a growing public health problem gotten through the consumption of contaminated food and water. A world health organization report, 2015 estimated 600million episodes of illness due to contaminated food worldwide. Amongst all age groups, Africa bore the greatest burden of diarrhoeal diseases. Gram-negative bacteria have become a significant challenge to the control of infection as a result of acquisition of antibiotic resistant genes. This is especially of concern in Nigeria where fermented condiments are important part of daily meals and sometimes consumed without cooking. This work thus identifies Gram negative bacteria from fermented condiments and evaluates the antibiotic resistance profile of the bacterial isolates. The fermented condiments- Iru (Parkia biglobosa) (67), Ogiri-igbo (Ricinus communis) (58), Ukpaka (Pentaclethra macrophylla) (22) and Okpei (Prosopis africana) (42), were obtained from markets in Abuja, Gboko, Lokoja, Okenne, Abeokuta, Ibadan, Ijebu-Ode, Ilorin, Lagos, Ondo and Ore. Coliform and faecal coliform test was done. Isolation of the Gram-negative bacteria was done using MacConkey agar. Taxonomic studies were carried out on the isolated Gram negative bacteria. Determination of antibiotic resistance profile of the Gram-negative bacteria was done by disc diffusion method. Ukpaka (Pentaclethra macrophylla) samples had the highest percentage occurrence of coliforms (100\%). Faecal coliform were more prevalent in Ukpaka (20\%) and Iru (16.67\%). Klebsiella pneumonia was prevalent in the 3 of the fermented condiments (Iru, Ogiri and Ukpaka). Escherichia coli was the most frequent Gram-negative bacteria in Okpei samples. The relatively high recovery rates of Gram-negative bacteria shows possible contamination of fermented condiments by human pathogens. The isolates from Ukpaka showed the highest resistance $(55.3 \%)$ to Cotrimoxazole. The effect of the resistance of Gram-negative bacteria to antibiotics could be transmission of resistant strains from farm to house, treatment failure and a limited choice of antibiotics used for treatment.

Keywords: antibiotic, resistance, food condiments and Nigeria

\section{Introduction}

Fermented condiments are popular in Nigeria, for the preparation of local delicacies giving indigenous meals their unique flavours. These fermented condiments are concentrated mix of plant produce and spices, often having a pungent smell and thus are used in milligram quantities. Traditionally, they are prepared by spontaneous solid-state fermentation of seeds which results in hydrolysis of the proteins and carbohydrates constituents of the seed. Fermentation essentially reduces the anti-nutritional factors of the seed, increases the nutrient composition, and improves its digestibility and flavour (Dosumu et al., 2012).

Fermented condiments are prepared and consumed around the globe. The four (4) most common fermented condiments in Nigeria are: Ukpaka, Iru, Okpei and Ogiri. Ukpaka is a fermented condiment made from African oil bean seed (Pentaclethra macrophyla). It is also known as Ugba and is popularly consumed in the south-eastern part of Nigeria. Okpei is prepared and consumed in south-east, Nigeria. It is made from mesquite seed (Prosopis africana) while Ogiri is prepared from pumpkin seeds (Achinewhu, 1986), or castor bean seeds (Ricinus communis), (Nwosu and Ojimelukwe, 1993) and also popular in south-east Nigeria. 
Iru is fermented African locust beans (Parkia biglobosa) which is dark brown in colour. It is known as Iru by the Yorubas in south-western Nigeria. Popular synonyms are Dadawa/Dawadawa by the Hausas in Northern Nigeria, Nététou in the Gambia/Senegal and Soumbala/Soumbara in Burkina Faso, Kpalugu in Ghana, and Khinda in Sierra Leone (Ogunshe and Okerre, 2011).

Pathogens in African indigenous fermented foods have been reported by several researchers (Gadaga, 2004; Enujiugha and Badejo, 2002; Ogunshe et al. 2006, 2008). Like most traditional fermented foods, fermented condiments are often prepared at home, by uncontrolled fermentation resulting in unpredictable diversity of microorganisms associated with the fermentation and varied qualities of the product. Antibiotic resistant strains have also been reported in bacteria of food origin (Olukoya et al., 1993; Ogunshe et al., 2008). Most studies however, are focused on bacteria associated with fermentation and antibiotic resistance among them. Resistance among food borne pathogens is a major public health risk requiring continuous surveillance. In Nigeria, surveillance is rarely complete and untimely (Isere et al., 2015). According to World Health Organization Regional Office for Africa Brazzaville (2012), surveillance seeks to: “(i) estimate burden of disease in order to determine the magnitude of the problem; (ii) monitor trends and know whether the situation is improving or worsening; (iii) detect outbreaks to determine urgent action; (iv) assess control programmes to obtain information on performance; and (v) generate data to be used for risk analysis and ensure safety of food supplies". This work identifies Gram negative food borne bacteria from fermented condiments and evaluates the antibiotic resistance profile of the bacteria isolated.

\section{Materials and Methods}

\section{Collection of fermented condiments}

The fermented condiments-Iru, Ogiri, Ukpaka and Okpei, were obtained from various markets in Abuja, Gboko, Lokoja, and Okenne which are located in the middle-belt, Nigeria and Abeokuta, Ibadan, Ijebu-Ode, Ilorin, Lagos, Ondo and Ore, located in South-West Nigeria.

\section{Total coliform test/Faecal coliform test}

Coliform test: $2 \mathrm{ml}$ of Mac Conkey broth was dispensed into test tubes. To detect gas production, Durham tubes were placed into each tube, stoppered with cotton plugs and autoclaved. After sterilization, $1 \mathrm{ml}$ of each sample was introduced aseptically into each tube and incubated at $35^{\circ} \mathrm{C}$ for $48 \mathrm{~h}$. Uninoculated tube served as control. Readings were obtained after $48 h$.

Faecal coliform test: Mac Conkey broth was prepared similarly, and $2 \mathrm{ml}$ of it, dispensed into test tubes. Durham tubes were placed into each tube and sterilized at $121^{\circ} \mathrm{C}$ for $15 \mathrm{~min}$. After sterilization, $1 \mathrm{ml}$ of each sample was introduced aseptically into each tube and incubated at $45^{\circ} \mathrm{C}$ for $48 \mathrm{~h}$. Uninoculated tube served as control. Readings were obtained after $48 \mathrm{~h}$. 


\section{Isolation and characterization of Gram-negative bacteria}

One millilitre $(1 \mathrm{ml})$ of the diluted samples of the various fermented condiments was inoculated into sterile Mac Conkey broth and incubated at $35^{\circ} \mathrm{C}$ for $24 \mathrm{~h}$. A $24 \mathrm{hr}$-old broth culture was streaked on sterile Mac Conkey agar plates and incubated at $35^{\circ} \mathrm{C}$ for $24 \mathrm{~h}$. The characteristics of the purified isolates were observed on Mac Conkey agar, Eosin methylene blue (EMB) agar, Triple Sugar Iron (TSI) agar, Cystine Lactose Electrolyte Deficiency (CLED) agar. Cultural, morphological, biochemical and physiological characteristics of the pure cultures of isolated Gram negative bacteria were determined.

\section{Determination of antibiotic resistance of the Gram-negative bacteria}

Antibiotic resistance profile was determined using disc diffusion method (Bauer et al., 1966). Sterile Mueller-Hinton agar plates were streaked with $0.1 \mathrm{ml}$ of $24 \mathrm{~h}$ old broth of bacterial isolates using sterile swab sticks and this was allowed to stand for $15 \mathrm{~min}$. Using sterile

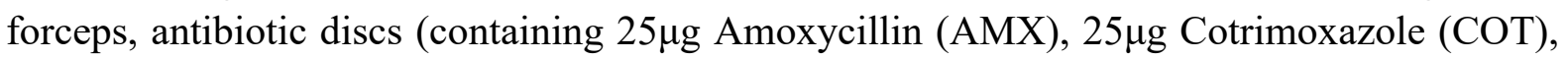

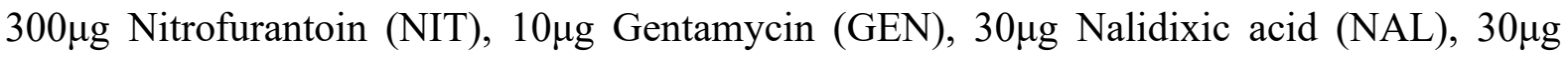

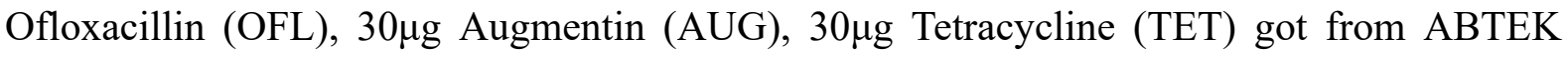
Biologicals Ltd. (Liverpool, UK) were aseptically placed on the Mueller-Hinton agar. It was then incubated at $35^{\circ} \mathrm{C}$ for $24 \mathrm{~h}$. Zones of inhibition were measured and the diameter, recorded in millimetre. Zones of inhibition less than $10 \mathrm{~mm}$ were considered resistant. The percentage resistance were calculated by multiplying the product of resistant isolates to total number isolates exposed to a given antibiotics.

\section{Result}

A total of 189 fermented condiments Iru (67), Ogiri (58), Ukpaka (22) while Okpei (42)] were obtained from the various markets.

Total coliform test result as shown in Fig.1 indicate that Ukpaka samples had the highest occurrence of total coliforms (100\%) with total coliforms occurring in all the samples. The percentage occurrence of coliforms in Ogiri samples was $91.67 \%$ and $77.77 \%$ in Okpei. The result of the faecal coliform test Fig. 1 indicate that the faecal coliforms are more prevalent in Ukpaka samples (20\%) followed by Iru samples (16.67\%). The percentage occurrence of the faecal coliforms in Okpei and Ogiri samples were $11.11 \%$ and $8.33 \%$ respectively.

The appearance of the Gram-negative bacteria recovered from the fermented condiments, on different agar medium, was used in the identification (Table 2). Result of the percentage recovery rates of the Gram-negative bacteria isolated from Iru samples shows that Klebsiella pneumonia was the predominant Gram-negative bacteria recovered, followed by Enterobacter sp. while Proteus mirabilis had the least percentage recovery rate. A similar observation was made in samples from Ogiri as shown in Table 1. The most recovered Gram-negative bacteria from Ukpaka sample were Enterobacter sp. followed by Klebsiella pneumonia, Citrobacter sp. and Salmonella spp. were the least recovered. Escherichia coli was the most abundant in Okpei samples while Citrobacter sp. and Proteus mirabilis were recovered the least. 


\section{Macrothink}

The Gram-negative bacteria isolated from the indigenous fermented condiments in this study displayed varied antibiotics resistance profiles. The isolates from Ukpaka had the highest resistance $(55.3 \%$ ) against cotrimoxazole. This was followed by $42.1 \%$ resistance against tetracycline figure 2. The least resistance was recorded in nitrofurantoin with $(2.56 \%)$ resistance. As shown in figure 2, the Gram-negative bacteria isolated from Okpei samples, gave a high resistance against cotrimoxazole (54.5\%) however, no resistance was observed against nalidixic acid and ofloxacillin. The Gram-negative bacteria from Iru also gave a high resistance against cotrimoxazole $(45.8 \%)$ while no resistance was observed against nitrofurantoin and ofloxacillin. Among isolates from Ogiri samples, resistance against tetracycline (50\%) and cotrimoxazole (45\%) was high and least against ofloxacillin (5\%). No resistance was recorded against ofloxacillin in three of the samples; Iru, Ukpaka and Okpei. $50 \%$ of the Gram negative isolates from Ogiri were resistant to the antibiotics tetracycline while greater than $50 \%$ of the Gram negative isolates from Ukpaka and Okpei were resistant to the antibiotics cotrimoxazole.

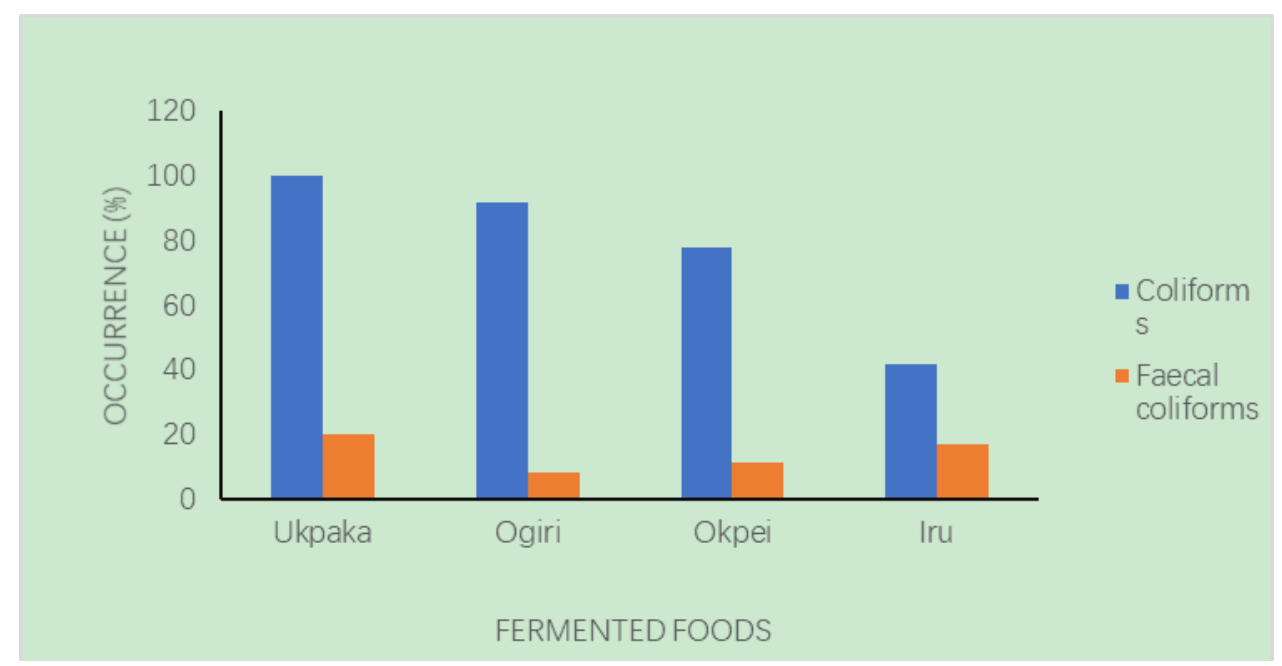

Figure 1. Percentage occurrence of coliforms and faecal coliforms in the fermented condimetns 


\section{Macrothink}

Journal of Biology and Life Science

ISSN 2157-6076 2020, Vol. 11, No. 1

Table 1. Percentage recovery rates of Gram-negative bacteria isolated from the fermented condiments

\begin{tabular}{lllll}
\hline & \multicolumn{4}{c}{ Condiments (Recovery rate in \%) } \\
\cline { 2 - 5 } Bacteria & Iru & Ogiri & Okpei & Ukpaka \\
\hline Citrobacter sp. & 11.6 & 7.6 & 9.6 & 5.5 \\
E.coli & 8.7 & 17.6 & 38.4 & 14.5 \\
Enterobacter sp. & 20.3 & 21.0 & 6.8 & 3.6 \\
Klebsiella pneumonia & 23.9 & 26.1 & 16.4 & 18.2 \\
$\begin{array}{l}\text { Proteus } \\
\text { Pseudomonas }\end{array}$ & 8.0 & 7.6 & 6.8 & 8.2 \\
aeruginosa & 10.9 & 10.9 & 11.0 & 10.9 \\
$\begin{array}{l}\text { Salmonella sp } \\
\text { S }\end{array}$ & 16.7 & 9.2 & 11.0 & 5.5 \\
\hline
\end{tabular}

Table 2. Colonial growth characteristics of the Gram-negative bacteria on MacConkey, EMB and CLED agar

\begin{tabular}{|c|c|}
\hline Characteristics & Isolate \\
\hline \multicolumn{2}{|l|}{ MCA/ EMB agar } \\
\hline \multicolumn{2}{|l|}{ Lactose negative isolates } \\
\hline Small colourless colonies on MCA/ EMB agar & Salmonella sp. \\
\hline Lactose positive isolates & \\
\hline $\begin{array}{l}\text { Red colonies on MCA } \\
\text { Dark-purple colonies with green metallic sheen } \\
\text { on EMB agar }\end{array}$ & $\begin{array}{l}\text { E.coli, Klebsiella pneumonia, Citrobacter, } \\
\text { Enterobacter sp. }\end{array}$ \\
\hline \multicolumn{2}{|l|}{ CLED agar } \\
\hline Yellow opaque colonies & E.coli \\
\hline Transluscent blue colonies & Proteus mirabilis \\
\hline Yellow/whitish/blue mucoid colonies & Klebsiella pneumonia \\
\hline Blue flat colonies & Salmonella sp. \\
\hline
\end{tabular}




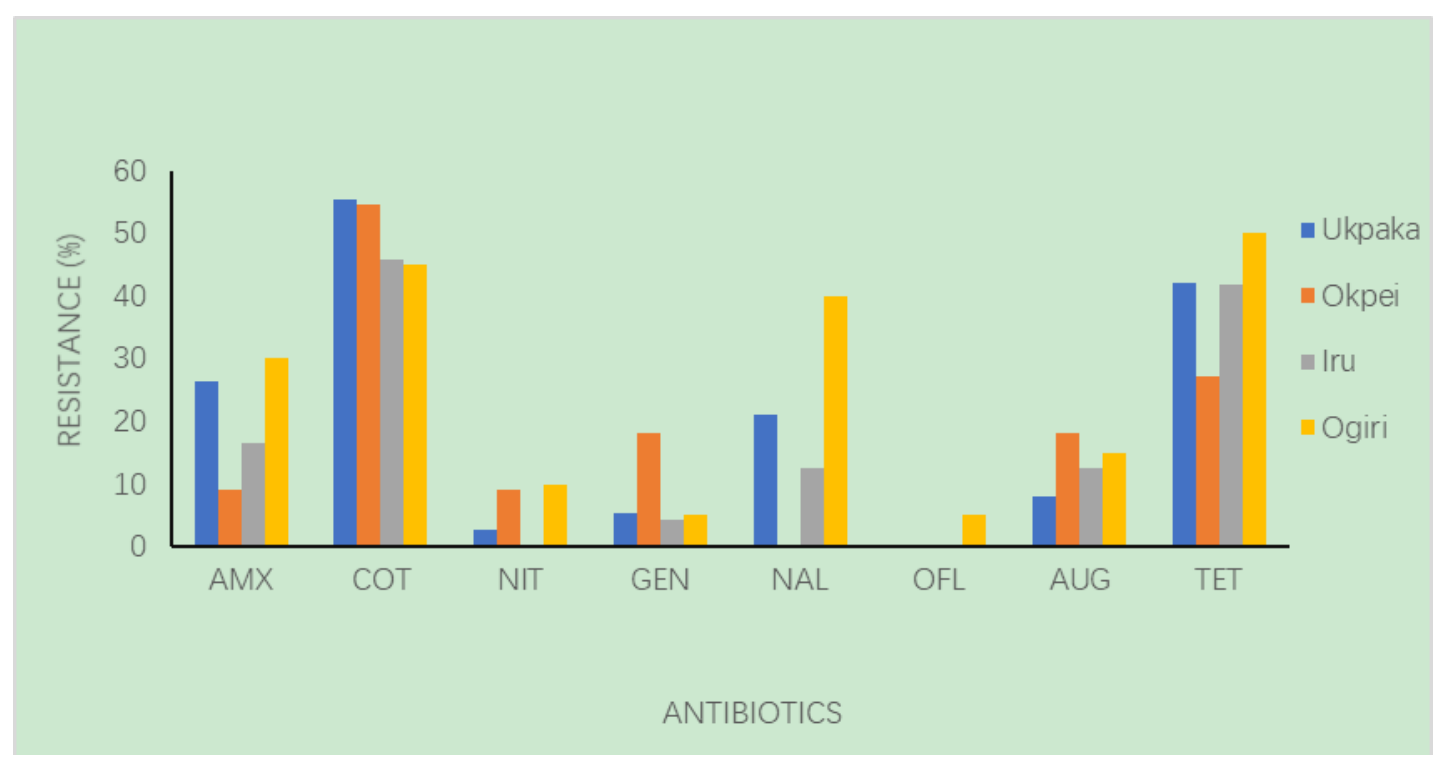

Figure 2. Percentage antibiotic resistance profile of Gram negative bacteria isolated from fermented condiments

\section{Discussion}

The sanitary quality of foods is usually determined by evaluating the content of indicator organisms. Results obtained in this study shows that indicator Gram-negative bacteria species were highly prevalent in fermented food condiments, with the total coliform and faecal coliforms most prevalent in Ukpaka samples. The presence of indicator organisms in food is an index of possible contamination of the food by human pathogens.

Indigenous fermented food condiments are usually prepared at home under unhygienic conditions and this can result in poor quality of the finished product. The Gram-negative bacteria obtained from this study- E. coli, Enterobacter sp., Klebsiella pneumonia, Citrobacter sp., Proteus mirabilis, Pseudomonas sp., and Salmonella sp. are similar to those of previous studies on similar fermented condiments. Enterobacter cloacae and Pseudomonas sp. have been isolated from fermenting Pentaclethra macrophylla seeds during the production of Ugba (Barber et al., 1988). Pseudomonas sp., Proteus sp. and Enterobacter aerogenes have also been isolated by Odunfa, (1981), Ogbadu and Okagbue, (1988) and Odibo et al., (1992) from fermenting castor oil seeds (Ricinus communis) during Ogiri production. Microorganisms isolated from Iru samples include Pseudomonas sp. (Ogbadu and Okagbue, 1988) as well as Proteus, Klebsiella, and E.coli (Odibo et al., 1992; Ogunshe and Olasugba, 2008; Enujiugha, 2009).

Usually, the focus of the food microbiologist is on studies of microbial flora of industrial importance, especially in selection of starter cultures for fermented foods (Ogunshe and Okere, 2011). In this study, the relatively high recovery rates of Gram-negative indicator bacteria are of medical importance and a public health concern. The water used in the fermentation of these condiments is a likely source of contamination as the water sourced for the preparation is essentially surface water, which can be exposed to environmental contaminants and is therefore unhygienic. Because the condiments are mostly prepared in 
rural areas, the water used is usually obtained from streams, rivers, ponds, shallow and deep wells. Food handlers also play an important role as vectors. Inadequate hygiene which includes improper washing of hands and cooking utensils before preparation is also an important source of contamination. Other likely sources of contamination include low public awareness of antimicrobial resistance specifically with regards to one's health approach which encourages disease vectors such as cockroaches, rats and flies (King et al., 2000).

The Gram-negative bacteria isolated from the fermented condiments in this study have all been involved in previous studies on aetiologic agents of gastroenteritis (Okeke and Nataro, 2001; CDC, 2002) and food poisonings (Mead et al., 1999). Food borne disease is a serious public health problem especially in developing countries and WHO has estimated that food borne disease caused by ingestion of contaminated food and water is the third leading cause of death in developing countries (King et al., 2000).

Resistance to antibiotics is another public health concern. Antibiotic resistance is the ability of a microorganism to resist the bacteriocidal or bacteriostatic activity of an antibiotic beyond the normal susceptibility of the specific bacterial species (Acar and Rostel, 2001; Mathur and Singh, 2005; McDonnell and Russell, 1999). In this study, Ofloxacillin was least resisted among the Gram-negative bacteria isolated from the fermented condiments. A similar finding was also made by Ogunshe et al., (2011) on Gram-negative bacteria isolated from Iru processing water.

In this study also, the antibiotics, Co-trimoxazole was resisted most by the Gram-negative bacteria isolated from the fermented food condiments. Other researchers Ogunshe et al., 2008; Ogunshe et al., 2012 made similar observations. Co-trimoxazole is a mixture of the drugs, sulphamethoxazole and trimethoprim, used to treat some bacterial infections, like pneumonia, bronchitis, and 'travelers' diarrhea. It is also used to treat ear, intestinal and urinary tract infections. The effect of the resistance of pathogenic bacteria to antibiotics is potential treatment failure and limited choice of antibiotics used for treatment. Antibiotic resistance may also result in greater risk of increased virulence and this may arise because of a co-selection of resistance and virulence properties (Gooderham and Hancock, 2009; Guerra et al., 2004).

Since antibiotic resistant bacteria can be found in the soil, in water and in human or animal faeces. The fermented condiments used in the study may have been contaminated with antibiotic resistant bacteria and/or antibiotic resistant genes through cross-contamination with antibiotic resistant bacteria during processing. Some of the fermented condiments such as Iru and Ukpaka which may be ingested without any prior cooking may present a high risk of transfer of antibiotic resistance strains, since antibiotic resistant bacteria present are not exposed to heat. Another problem with the presence of antibiotic resistance gene in food is that it increases the gene pool from which pathogenic bacteria can pick up antibiotic resistance genes and transfer them to other pathogenic bacteria. The resistance of the foodborne Gram-negative bacteria pathogens to antibiotics results in an increase in the number of hospital visitations and increases the risk of invasive infections and death (Verraes et al., 2013). 
It can be concluded from the present study that Gram-negative bacteria are prevalent in the four most consumed Nigerian indigenous fermented condiments. The prevalence of these Gram-negative bacteria in the fermented condiments suggests that measures that minimize the risk of food-borne illnesses should be taken as well as public awareness of antibiotic resistance and food safety training of local producers of these condiments. Finally, Hazard Analysis and Critical Control Point (HACCP), Good Manufacturing Practices (GMP) and Good Hygienic Practices (GHP) should be encouraged during the processing of fermented condiments.

\section{References}

Acar, J., \& Rostel, B. (2001). Antimicrobial resistance: An overview. Rev. Sci. Tech. OIE, 20, 797-810. https://doi.org/10.20506/rst.20.3.1309

Achinewhu, S. C. (1986). Some Biochemical and Nutritional Changes During the Fermentation Fluted Pumpkin (Telferia occidentalis). Qualitas Plantarum. Plant Foods for Human Nutrition, 36, 97-106. https://doi.org/10.1007/BF01092137

Barber, L., Achinewhu, S. C., \& Ibiama, E. M. (1988). The microbiology of Ogiri production from castor seeds (Ricinus communs). Food Microbiol, 5, 177-182. https://doi.org/10.1016/0740-0020(88)90016-0

Bauer, A. W., Kirby, W. M., Sherris, J. C., \& Turck, M. (1966). Antibiotic susceptibility testing by a standardized single disk method. Am J Clin Pathol., 45(4), 493-496. https://doi.org/10.1093/ajcp/45.4_ts.493

CDC (2002). Coliform bacteria and drinking water. Centers for Disease Control and Prevention, Atlanta.

Dosumu, O. O., Oluwaniyi, O. O., Awolola, G. V., \& Oyedeji, O. O. (2012). Nutritional Composition and Antimicrobial Properties of Three Nigerian Condiments. Nigerian Food Journal, 30(1), 43-52. https://doi.org/10.1016/S0189-7241(15)30012-6

Enujiugha, V. N., \& Badejo, A. A. (2002). Cultural Alteration for the improvement of Bacillus subtilis in the fermentation of African oil bean seeds (Pentaclethra macrophylla Benth). Applied Tropical Agriculture, 7, 6-1.

Gadaga, T. H., Nyanga, L. K., \& Mutukumira, A. N. (2004). The occurrence, growth and control of pathogens in African fermented foods. African Journal of Food, Agriculture, Nutrition and Development, 4(1). https://doi.org/10.4314/ajfand.v4i1.19155

Gooderham, W. J., \& Hancock, R. E. W. (2009) Regulation of virulence and antibiotic resistance by two-component regulatory systems in Pseudomonas aeruginosa. FEMS Microbiol. Rev,. 33, 279-294. https://doi.org/10.1111/j.1574-6976.2008.00135.x

Guerra, B., Junker, E., Miko, A., Helmuth, R., \& Mendoza, M. C. (2004). Characterization and localization of drug resistance determinants in multidrug-resistant, integron-carrying Salmonella enterica serotype Typhimurium strains. Microb. Drug Resist., 10, 83-91. https://doi.org/10.1089/1076629041310136 
Isere, E. E., Fatiregun, A. A., \& Ajayi, I. O. (2015). An overview of disease surveillance and notification system in Nigeria and the roles of clinicians in disease outbreak prevention and control. Nigerian Medical Journal: Journal of the Nigeria Medical Association,56(3), 161-168. https://doi.org/10.4103/0300-1652.160347

King, J. C., Robert, E. B., Michael, P. D., Kevin, L. F., Brenda, H. H., Orville, A. L., ... Catherine, E. W. (2000). Foodborne Illnesses and Nutritional Status: A Statement from an American Society for Nutritional Sciences Working Group, The Journal of Nutrition, 130(10), 2613-2617. https://doi.org/10.1093/jn/130.10.2613

Mathur, S., \& Singh, R. (2005). Antibiotic resistance in food lactic acid bacteria-A review. Int. J. Food Microbiol., 105, 281-295. https://doi.org/10.1016/j.ijfoodmicro.2005.03.008

McDonnell, G., \& Russell, A. D. (1999). Antiseptics and disinfectants: Activity, action and resistance. Clin. Microbiol. Rev. 12, 147-179. https://doi.org/10.1128/CMR.12.1.147

Mead, P., Slutsker, L., Dietz, V., McCaig, L., Bresee, J., Shapiro, C., Griffin, P., \& Tauxe, R. (1999). Food-related illness and death in the United States. Emerg. Infect. Dis. 5, 607-625. https://doi.org/10.3201/eid0505.990502

Nwosu, C. D., \& Ojimelukwe, P. C. (1993). Improvement of the traditional method of ogiri production and identification of the microorganisms associated with the fermentation process. Plant Foods Hum. Nutr., 43, 267-272. https://doi.org/10.1007/BF01886229

Odibo, F. J. C., Ugwu,. D. A., \& Ekeoha, D. C. (1992). Microorganisms associated with the fermentation of Prosopis seeds for Ogiri-Okpei production. J. Food Sci. Technol. (Mysore), 29, 306-307.

Odunfa, S. A. (1981). Microbiology and amino acid composition of Ogiri - a food condiment from fermented melon seeds. Die Nahrung., 25, 811-816.

https://doi.org/10.1002/food.19810250903

Ogbadu, C. O., \& Okagbue, R. N. (1988). Bacterial fermentation of soybeans for daddawa production. J. Appl. Bacteriol., 65, 353-356.

https://doi.org/10.1111/j.1365-2672.1988.tb01902.x

Ogunshe, A. A. O., \& Okereh, J. N. (2011). Processing-Water as Source of Gram-negative Foodborne Indicator Bacteria in Traditionally-produced Iru. Research Journal of Microbiology, 6, 587-598. https://doi.org/10.3923/jm.2011.587.598

Ogunshe, A. A. O., \& Olasugba, K. O. (2008). Microbial loads and incidence of food-borne indicator bacteria in most popular indigenous fermented food condiments from middle-belt and Southwestern Nigeria. Afr. J. Microbiol. Res., 2, 332-339.

Ogunshe, A. A. O., Ayodele, A. E., \& Okonko, I. O. (2006). Microbial studies on Aisa: A potential indigenous laboratory fermented food condiment from Albizia saman (Jacq.) F. mull. Pak. J. Nutr., 5, 51-58. https://doi.org/10.3923/pjn.2006.51.58

Ogunshe, A. A. O., Obiora-Okeke, C. M., \& Olurin, T. O. (2008). Bioinhibition of 


\section{Macrothink}

phenotypes of Gram-negative food indicator bacteria from some Nigerian fermented food condiments. Food, 2, 152-158.

Okeke, I., \& Nataro, J. P. (2001). Enteroaggregative E. coli. Lancet: Infectious Diseases 1, 304-307. https://doi.org/10.1016/S1473-3099(01)00144-X

Olukoya, D. K., Idika, N. \& Odugbemi T. (1993) Antibacterial activity of some medicinal plants from Nigeria. Journal of Ethno pharmac., 39, 69-72. https://doi.org/10.1016/0378-8741(93)90051-6

Verraes, C., Boxstael, S. V., Meervenne, E. V., Coillie, E. V., Butaye, P., Catry, B., ... Herman, L. (2013). Antimicrobial Resistance in the Food Chain: A Review. Int. J. Environ. Res. Public Health, 10(7), 2643-2669. https://doi.org/10.3390/ijerph10072643

World Health Organization Regional Office for Africa Brazzaville (2012). Manual for Integrated Foodborne Disease Surveillance in the WHO African Region.

\section{Copyright Disclaimer}

Copyright for this article is retained by the author(s), with first publication rights granted to the journal.

This is an open-access article distributed under the terms and conditions of the Creative Commons Attribution license (http://creativecommons.org/licenses/by/4.0/). 